\title{
Does Audit Quality Moderate the Relationship between Accounting Information and the Share Price? Evidence from Jordan
}

\author{
Yazan Oroud $^{1}$, Md. Aminul Islam², Tunku Salha Tunku Ahmad ${ }^{2} \&$ Anas Ghazalat ${ }^{3}$ \\ ${ }^{1}$ Faculty of Business, Isra University, Amman, Jordan \\ ${ }^{2}$ School of Business Innovation and Technopreneurship, Universiti Malaysia Perlis (UniMAP), Malaysia \\ ${ }^{3}$ College of Business, Arab Open University, Jordan \\ Correspondence: Yazan Oroud, Accounting Department, Faculty of Business, Isra University, Amman, Jordan.
}

Received: December 3, 2018

Accepted: January 17, $2019 \quad$ Online Published: February 11, 2019

doi:10.5539/ibr.v12n3p58

URL: https://doi.org/10.5539/ibr.v12n3p58

\begin{abstract}
Effect of accounting information on the share price has been having the share of attention from researchers for over six decades owing to the increasing of global financial crisis. Hence, this study attempts to contribute to literature by investigating such relationship in Jordan, a developing country. Specifically, this study investigates the relationship between the cash flow and accruals on share price of listed companies on Amman Stock Exchange for the year 2002 to 2014 also the effect of financial crisis on the share price before and after 2008. The model of this study was theoretically founded on both the agency and the signaling theories. To examine the developed model, the required data were gathered from the annual reports of 236 listed Companies. In analyzing the data, this study utilized the panel data methodology on 117 companies with 1521 observations. Moreover, this study used audit quality (audit firm size and audit tenure) as moderating variable. Based on the panel data results, the fixed effect model was used to examine the effect of the cash flows and accruals on the share price. The accruals and cash flows combined have significant effects on the share prices of the Jordanian companies listed on ASE. Audit quality, whether auditor's firm size or auditor's tenure, has significant moderating effect on associations of the share prices with accruals and with cash flows and the 2008 financial crisis had negative effects on share prices of the Jordanian companies listed on ASE. This study provides deep insights into relative usefulness of cash-based and accrual-based accounting measures and assist investors, regulators, analysts, and other stakeholders in evaluating the liquidity and financial performance of Jordanian companies listed on ASE, which may result in better allocation of economic resources by enabling the investors to take informed investment decisions, thus promoting a more efficient Jordanian capital market.
\end{abstract}

Keywords: cash flow, accruals, audit quality, share price, agency theory, signalling theory, fixed-effect, financial crisis, ASE

\section{Introduction}

Financial statements are the fundamental source of information in the capital markets. It is argued that high quality of audit will improve the perceptions of reliability for the users (investors and shareholders) of this information. One of the basic functions of the external auditors is to impart credibility on financial reports by assessing, independently, the accuracy and fairness of the information presented in the reports. There is evidence (e.g., Balsam, Krishnan \& Yang (2003), Krishnan (2003), and Khurana \& Raman (2004)) supporting that improved audit quality increases perceived reliability of the financial statements. Some researchers (e.g., Doyle, Ge \& McVay (2007) and Drake, Myers \& Myers (2009)) provided evidence indicating that quality of financial reporting affects accruals and that a low-quality audit means a high level of mispricing.

The fundamental facets of forecasting the share price is to find roots in the financial theory which considers the share prices to be equal to the current value of the estimated (predicted) future cash flows (Keown, Martin, Petty \& Scott, 2005; Watson \& Head, 2007 Oroud et al., 2017). It is argued that firms' share prices in an efficient market hold information about, and reflect, anticipated future benefits. Previous research (e.g., Charitou, Clubb \& Andreou (2001), Pourheydari \& Ahmadi (2008), and Penman \& Yehuda (2009)) supports this perspective and provides evidence on that share price is associated significantly with reported operating cash flows (OCFs) and earnings. 
The stakeholder theory, the signalling theory, and the agency theory of inspired confidence define auditing as a mechanism for mitigating information asymmetries amongst involved parties (Okolie, Izedonmi \& Enofe, 2013; Okolie, 2014). The high auditing quality treats information asymmetry and reduces the uncertainties related to earnings. Owing to that audit quality is not observable directly, early researchers employed varied proxies to approach it and study its impacts. The most common means of quantifying audit quality is 'Brand Name', which may also be expressed as auditor's firm size (Reynolds \& Francis, 2000; Khurana \& Raman, 2004, Oroud et al., 2016), and industry specialization (Balsam et al., 2003; Moroney, 2007). On the other hand, Caramanis and Lennox (2008) employed audit engagement hours as proxy for audit quality and found that quality of client's earnings is better when the auditors expend more time on audit engagements. Moreover, Gunny and Zhang (2009) established link between audit quality, approached by auditor's rank, and client's earnings quality. They reported that clients of auditors with higher rank had higher earnings quality, and vice versa.

Numerous studies such as; Chotkunakitti (2005), Lorek and Willinger (2009), Daraghma (2010), Waldron and Jordan (2010), and Ebaid (2011) Oroud et al. (2016) investigated the ability of accruals and cash flows to provide forecasts of future Operating Cash Flows (OCFs). However, those studies obtained varying and inconsistent, even contradictory, findings. Furthermore, a major line of research investigated the additional explanatory power of accruals via disaggregating earnings into the OCF and accrual components of earnings and then holding comparisons between the predictive capacities of OCFs, earnings, and the combination of OCFs and aggregated/disaggregated accruals. These studies reported conflicting results. Some studies Barth, Cram \& Nelson (2001), Al-Attar \& Hussain (2004), and Ebaid (2011) found that disintegrating earnings into aggregated accruals and individual OCFs enhances the predictive capability of earnings and that further disintegration of accruals into individual accrual components like accounts payable changes, accounts receivable changes, depreciation and amortization expenses, and inventory changes further raises the predictive capability of earnings. Though, Chotkunakitti (2005) presented conflicting evidence on that OCFs as the only predictor are superior to OCFs plus aggregated/disaggregated accruals and to earnings. Other studies (e.g., Khadash, Badran \& Nassar (2013)) even reported no significant difference between OCFs alone and OCFs plus accruals as predictors of share prices of companies. These inconclusive results indicate a knowledge gap that merits further investigation.

However, none of these studies provided any direct empirical evidence affirming the comparative capabilities of the studied variables to explain share price of companies or investigated whether or not audit quality has a significant moderating effect on the relations of share prices of companies with the corresponding accruals and cash flows. Furthermore, the effect of financial crisis on this nexus.

\section{Research Methodology}

The researchers developed a research framework for this study that examines the links between cash flows, accruals, audit quality, and share prices of companies. data on the independent research variables in this study are information that is provided by the management of the companies, whether in the financial list or the in the financial position (or status), which are prepared according to the accrual basis of accounting, in addition to the cash flows list, which is prepared according to the cash flow accounting basis. As the Agency Theory states on necessity of conflict of interests between the management which prepares these data and the business owners, who represent the shares in the company, which is the dependent variable in the present study, then the research model attempted to explain this relationship on the basis of the Agency Theory. As well, the information which the management holds are much more than what it presents through the financial reports. Hence, the feedback derived from the share prices will be explained as an indicator of the quality of the financial information prepared according to the cash flow and the accruals accounting bases through the Signalling Theory. Since the Agency Theory defined the audit process as the mechanism through which quality of the financial information can be confirmed, then this study tested the potential for the audit quality variable to serve as a moderator of the relationship between the independent variables and the dependent variable, hoping that audit quality will positively influence the share prices through its anticipated role in enhancing efficiency and quality of the financial reports. 


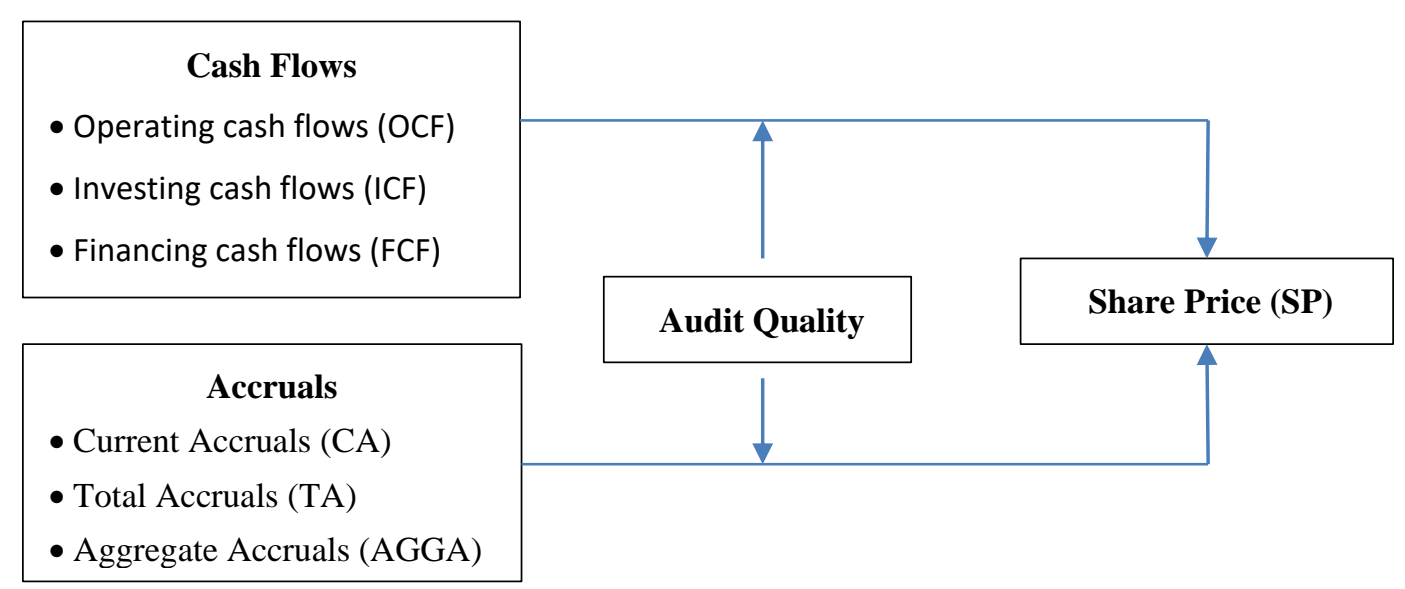

Figure 1. Research Framework

The regression analysis is used to investigate the relationship between financial components on the ASE and the share price. The regression analysis result is an equation appearing the most accurate prediction of the dependent variable on the basis of the independent variables. This method is used in cases where the independent variables are interrelated with one another and with the dependent variable.

Model 1: $\quad S P_{i t}=\alpha+\beta_{1} O C F_{i t}+\beta_{2} I C F_{i t}+\beta_{3} F C F_{i t}+\varepsilon_{i t}$

Model 2: $S P_{i t}=\alpha+\beta_{1} C A_{i t}+\beta_{2} T A_{i t}+\beta_{3} A G G A_{i t}+\varepsilon_{i t}$

Model 3: $S P_{i t}=\alpha+\beta_{1} O C F_{i t}+\beta_{2} I C F_{i t}+\beta_{3} F C F_{i t}+\beta_{4} C A_{i t}+\beta_{5} T A_{i t}+\beta_{6} A G G A_{i t}++\varepsilon_{i t}$

Model 4:

a) $S P_{i t}=\alpha+\beta_{1} O C F_{i t}+\beta_{2} I C F_{i t}+\beta_{3} F C F_{i t}+\beta_{4} F S_{i t}+\beta_{5} O C F_{i t}{ }^{*} F S_{i t}+\beta_{6} I C F_{i t}{ }^{*} F S_{i t}+\beta_{7} F C F_{i t}{ }^{*} F S_{i t}+\varepsilon_{i t}$

b) $S P_{i t}=\alpha+\beta_{1} C A_{i t}+\beta_{3} T A_{i t}+\beta_{3} A G G A_{i t}+\beta_{4} F S_{i t}+\beta_{5} C A_{i t}{ }^{*} F S_{i t}+\beta_{6} T A_{i t}{ }^{*} F S_{i t}+\beta_{7} A G G A_{i t}{ }^{*} F S_{i t}+\varepsilon_{i t}$

c) $S P_{i t}=\alpha+\beta_{1} O C F_{i t}+\beta_{2} I C F_{i t}+\beta_{3} F C F_{i t}+\beta_{4} A T_{i t}+\beta_{5} O C F_{i t}{ }^{*} A T_{i t}+\beta_{6} I C F_{i t}{ }^{*} A T_{i t}+\beta_{7} F C F_{i t}{ }^{*} A T_{i t}+\varepsilon_{i t}$

d) $S P_{i t}=\alpha+\beta_{1} C A_{i t}+\beta_{2} T A_{i t}+\beta_{3} A G G A_{i t}+\beta_{4} A T_{i t}+\beta_{5} C A_{i t}{ }^{*} A T_{i t}+\beta_{6} T A_{i t}{ }^{*} A T_{i t}+\beta_{7} A G G A_{i t}{ }^{*} A T_{i t}+\varepsilon_{i t}$

Model 5: $S P_{i t}=\alpha+\beta_{1} O C F_{i t}+\beta_{2} I C F_{i t}+\beta_{3} F C F_{i t}+\beta_{4} D Y_{i t} \varepsilon_{i t}$

Model 6: $S P_{i t}=\alpha+\beta_{1} C A_{i t}+\beta_{2} T A_{i t}+\beta_{3} A G G A_{i t}+\beta_{4} D Y_{i t}+\varepsilon_{i t}$

The research data were collected from ASE, as well as from the annual reports of the listed companies, in order to examine the relations of the share prices of these companies with their corresponding cash flows, accruals, and the audit quality. A total of 117 companies were listed on ASE during the period 2002-2014. These companies belong to three sectors: the financial, industrial, and service sectors. Companies belonging to the financial sectors were 50 companies, representing $42.7 \%$ of the whole listed companies. Companies of the industrial sector were 46 , comprising $39.3 \%$ of the listed companies. Meantime, the companies belonging to the service sector were 21 , that is, $18 \%$ of the companies in the study sample.

Table 1. Distribution of the sample companies by sector

\begin{tabular}{ccc}
\hline Sector & Number & Percentage \\
\hline Financial Sector & 50 & $42.7 \%$ \\
Industrial Sector & 46 & $39.3 \%$ \\
Services Sector & 21 & $18 \%$ \\
\hline Total & 117 & $100 \%$ \\
\hline
\end{tabular}

\section{Results}

\subsection{Accounting Information Models (Direct Relationship)}

This study applied fixed-effect multivariate regression analysis based on the results of Hausman and BreuschPagan Lagrange multiplier tests. In this type of analysis of panel data, testing for normality is unnecessary because this analysis is categorized within the distribution-free techniques (Henderson, Carroll \& Li, 2008).

Table 2 show that the three models fits, the data at the significance level of 0.01. In addition, this table discloses that the independent variables in the first model can explain 13.27\% of the variations in the SPs of the studied companies $\left(R^{2}=0.1327\right)$. The constant term of this model is positive and significant $(p<0.01)$. Additionally, second model shows that the independent variables explain $38.92 \%$ of the variations in the SPs of the listed companies $\left(R^{2}=0.3892\right)$. The constant term in this model is significant $(\alpha=.01)$ and positive. The third 
research model posits that the accruals and cash flows combined have significant effect on the share prices of the Jordanian companies listed on ASE, these results underline that the model fit the data at the level of significance of 0.01 . In this model, the independent variables explain $40.93 \%$ of the variations in the SPS of the studied companies $\left(R^{2}=0.4093\right)$. The constant term of this model is positive and significant $(p<0.01)$.

Table 2. Results of regression modelling

\begin{tabular}{|c|c|c|c|c|c|c|}
\hline \multirow{2}{*}{ Variable } & \multicolumn{2}{|c|}{ First Model } & \multicolumn{2}{|c|}{ Second Model } & \multicolumn{2}{|c|}{ Third Model } \\
\hline & Coefficients & $P>Z$ & Coefficients & $P>Z$ & Coefficients & $P>Z$ \\
\hline$O C F$ & 0.0739 & $0.006 * * *$ & - & - & 0.0724 & $0.004 * * *$ \\
\hline$I C F$ & -0.0371 & 0.325 & - & - & 0.0638 & 0.873 \\
\hline$F C F$ & -0.1093 & $0.083^{*}$ & - & - & 0.0967 & $0.039 * *$ \\
\hline$C A$ & - & - & 0.0031 & 0.725 & 0.0081 & 0.342 \\
\hline$T A$ & - & - & 0.728 & $0.000 * * *$ & 0.690 & $0.000 * * *$ \\
\hline$A G G A$ & - & - & 0.026 & $0.031 * *$ & 0.0490 & $0.026 * *$ \\
\hline _cons & 2.696 & $0.000 * * *$ & 2.471 & $0.000 * * *$ & 2.453 & $0.000 * * *$ \\
\hline$R$-sq overall & \multicolumn{2}{|c|}{$13.27 \%$} & \multicolumn{2}{|c|}{$38.92 \%$} & \multicolumn{2}{|c|}{$40.93 \%$} \\
\hline$(F-$ value $)$ & \multicolumn{2}{|c|}{$7.41 * * *$} & \multicolumn{2}{|c|}{$323.66 * * *$} & \multicolumn{2}{|c|}{$26.25 * * *$} \\
\hline
\end{tabular}

Investing Cash Flows, $C A=$ Current Accruals; $T A=$ Total Accruals; $A G G A=$ Aggregate Accruals

\subsection{Interaction Models}

This study investigated the role of the audit quality in moderating the relationships between share prices of companies and accruals and cash flows. Two measure of audit quality were considered: audit firm size and audit tenure. the moderating effect of a variable is examined by calculating the interaction between the independent variable and the moderator. In the current study, it happened that the new variables involved in the moderation process (i.e., the interaction variables or terms) suffer from the multicollinearity problem due to the interaction process which created them. In consequence, this study employed the mean-centered method for each moderator and explanatory variables before calculating the interaction so as to overcome this problem.

The method employed for solving the multicollinearity problem in these cases is dependent on researcher's preference as there are so far two common methods. The first method is mean-centered method. It subtracts the mean from the original value of the variable, hence, the mean is zero. The second method is called the standardization method. It applies the same steps of the mean-centered method and then divides the value by the standard deviation. This results in a mean of zero but a standard deviation of 1 (Dalal \& Zickar, 2012; Dawson, 2014). In effect, these two methods lead to identical results. In this section, the researcher discusses the results pertaining to the fourth regression model in the study which has been divided into four sub-models (A, B, C and D).

Table 3. Results of regression analysis related to Fourth Model- Audit Firm Size as a Moderator

\begin{tabular}{|c|c|c|c|c|}
\hline \multirow{2}{*}{ Variable } & \multicolumn{2}{|c|}{ Model A (Cash Flows) } & \multicolumn{2}{|c|}{ Model B (Accruals) } \\
\hline & Coefficients & $P>Z$ & Coefficients & $P>Z$ \\
\hline$O C F$ & 0.230 & $0.000 * * *$ & - & - \\
\hline$I C F$ & .0172 & $0.017 * *$ & - & - \\
\hline$F C F$ & 0.102 & 0.122 & - & - \\
\hline$A F S$ & -1.705 & 0.000 & - & - \\
\hline$O C F^{*} A F S$ & 0.0371 & $0.000 * * *$ & - & - \\
\hline$I C F * A F S$ & 0.0328 & $0.023 * *$ & - & - \\
\hline$F C F^{*} A F S$ & 0.0383 & 0.715 & - & - \\
\hline$C A$ & - & - & 0.679 & $0.000 * * *$ \\
\hline$T A$ & - & - & 0.827 & $0.017 * *$ \\
\hline$A G G A$ & - & - & 0.0352 & 0.114 \\
\hline$A F S$ & - & - & -0.128 & $0.000 * * *$ \\
\hline$C A * A F S$ & - & - & -0.015 & $0.000 * * *$ \\
\hline$T A * A F S$ & - & - & -0.003 & $0.022 * *$ \\
\hline _cons & 3.542 & $0.000 * * *$ & -0.026 & 0.756 \\
\hline R-sq overall & \multirow{2}{*}{\multicolumn{2}{|c|}{$\begin{array}{c}0.1114 \\
129.80 * * *\end{array}$}} & \multirow{2}{*}{\multicolumn{2}{|c|}{$\begin{array}{c}0.3979 \\
74.53 * * *\end{array}$}} \\
\hline (F-value) & & & & \\
\hline
\end{tabular}

\subsubsection{Interaction Models (Audit Quality- Audit Firm Size)}

Table 3 shows the results of the robust, fixed-effect regression analysis based on the results of the Hausman and Breusch-Pagan Lagrange multiplier tests. The analysis outcomes demonstrate that the two models are fit at the significance level of 0.01 . The results also indicate that in Model A the explanatory variables explain $11.14 \%$ of the variations in the SPs of the companies studied $\left(R^{2}=0.1114\right)$. On the other hand, the consistent term in this model is positive and significant $(p<0.01)$. Additionally, the analysis outcomes of Model B demonstrate that the model fit the data at the significance level of 0.01 . The results also indicate that in this model the explanatory 
variables explain $39.79 \%$ of the variations in the SPs of the companies studied $\left(R^{2}=0.3979\right)$. On the other hand, the consistent term in this model is positive and significant $(p<0.01)$.

\subsubsection{Interaction Models (Audit Quality- Audit Tenure)}

Table 4 illustrations the results of the robust, fixed-effect regression analysis based on the results of the Hausman and Breusch-Pagan Lagrange multiplier tests. The analysis outcomes show that the models C and D are fit at the significance level of 0.01 . The results also indicate that in Model C the independent variables explain $34.22 \%$ of the variations in the SPs of the companies studied $(\mathrm{R} 2=0.3422)$. On the other hand, the consistent term in this model is positive and significant $(\mathrm{p}<0.01)$. Additionally, the analysis outcomes of Model D reveal that the explanatory variables explain $40.87 \%$ of the variations in the SPs of the companies studied $(\mathrm{R} 2=0.4087)$. On the other hand, the consistent term in this model is positive and significant $(\mathrm{p}<0.01)$.

Tabel 4. Results of regression analysis related to Fourth Model- Audit Tenure as a Moderator

\begin{tabular}{|c|c|c|c|c|}
\hline \multirow[t]{2}{*}{ Variable } & \multicolumn{2}{|c|}{ Model C (Cash Flows) } & \multicolumn{2}{|c|}{ Model D (Accruals) } \\
\hline & Coefficients & $P>Z$ & Coefficients & $P>Z$ \\
\hline$\overline{\mathrm{OCF}}$ & 0.232 & $0.000 * * *$ & - & - \\
\hline $\mathrm{ICF}$ & -0.173 & $0.017 * *$ & - & - \\
\hline FCF & -0.104 & 0.114 & - & - \\
\hline $\mathrm{AT}$ & -2.060 & $0.000 * * *$ & - & - \\
\hline $\mathrm{OCF}^{*} \mathrm{AT}$ & -0.0376 & $0.000 * * *$ & - & - \\
\hline $\mathrm{ICF}^{*} \mathrm{AT}$ & 0.0331 & $0.022 * *$ & - & - \\
\hline $\mathrm{FCF}^{*} \mathrm{AT}$ & -0.0033 & 0.756 & - & - \\
\hline $\mathrm{CA}$ & - & - & 0.073 & $0.015 * *$ \\
\hline TA & - & - & 0.829 & $0.000 * * *$ \\
\hline AGGA & - & - & 0.0348 & $0.017 * *$ \\
\hline AT & - & - & -0.418 & 0.181 \\
\hline $\mathrm{CA}^{*} \mathrm{AT}$ & - & - & -0.016 & $0.002 * * *$ \\
\hline TA*AT & - & - & 0.0277 & $0.05 * *$ \\
\hline cons & 3.743 & $0.000 * * *$ & 0.0270 & 0.134 \\
\hline $\begin{array}{l}R \text {-sq overall } \\
\text { (F-value) }\end{array}$ & \multicolumn{2}{|c|}{$\begin{array}{c}0.1367 \\
34.22 * * *\end{array}$} & \multicolumn{2}{|c|}{$\begin{array}{c}40.87 \% \\
149.39 * * *\end{array}$} \\
\hline
\end{tabular}

This study is an investigation that managed and processed very recent, and bulky, financial data, covering a period of 13 years (2002 through 2014) that have been divided into two intervals: before the economic crisis (2002-2007), and after the economic crisis (2009-2014). Therefore, in this analysis, a dummy variable was incorporated so as to compare the time period preceding the financial crisis (2002-2007) with that following it (2009-2014).

The time period before the crisis $=0$; The time period after the crisis $=1$

\subsubsection{The Cash Flows Model with Financial Crisis}

Table 5 indicates that there is a significant $(p=0.000<.01)$ relationship between the variable relating to the financial crisis $\left(D_{Y}\right)$ and the share prices of the companies in the cash flows model and that the financial crisis has high influence on the cash flows model because the coefficients of the added variable indicate a decline in the share prices of nearly 0.835 JDs for each share. Moreover, there are declines in the coefficients of the model in general for all variables.

Table 5. The regression result of Model 5

\begin{tabular}{|c|c|c|c|}
\hline \multirow[t]{2}{*}{ Variables } & \multicolumn{3}{|c|}{$S P_{i t}=\alpha+\beta_{1} O C F_{i t}+\beta_{2} I C F_{i t}+\beta_{3} F C F_{i t}+\beta_{4} D Y_{i t}+\varepsilon_{i t}$} \\
\hline & Coefficients & (z-static) & $\mathrm{P}>\mathrm{Z}$ \\
\hline $\mathrm{OCF}$ & 0.639 & 2.43 & $0.017 * *$ \\
\hline ICF & -0.612 & -1.51 & 0.134 \\
\hline FCF & -1.280 & -2.03 & $0.044 * *$ \\
\hline DY & -0.8359 & -2.09 & $0.039 * * *$ \\
\hline _cons & 3.0959 & 7.56 & $0.000 * * *$ \\
\hline$R$-sq overall & $13.57 \%$ & & \\
\hline$(F-$ value $)$ & $54.93 * * *$ & & \\
\hline
\end{tabular}




\subsubsection{The Accruals Model with Financial Crisis}

Table 6 displays the results of the robust, fixed-effect regression modelling (that is, according to results of Hausman and Breusch-Pagan Lagrange multiplier tests $\left.23.69^{* * *}, 1811.68^{* * *}\right)$ using the regression correction with the Driscoll-Kraay standard errors method. The results point that the model fits the data at the 0.01 level of significance. Additionally, in this model the predictors explain $38.14 \%$ of the variations in the SPs of the listed companies $(\mathrm{R} 2=0.3814)$. The constant term in this model is significant $(\alpha=.01)$ and positive. Based on the foregoing findings (Table 10 and Table 11), it discerns that the financial crisis did negatively affect the companies listed on ASE in general and that it affected the financial lists prepared on the accruals and the cash flows accounting bases.

Table 6 . The regression result of the model 6

\begin{tabular}{|c|c|c|c|}
\hline \multirow[t]{2}{*}{ Variables } & \multicolumn{3}{|c|}{$S P_{i t}=\alpha+\beta_{1} C A_{i t}+\beta_{2} T A_{i t}+\beta_{3} A G G A_{i t}+\beta_{4} D Y_{i t}+\varepsilon_{i t}$} \\
\hline & Coefficients & (z-static) & $\mathrm{P}>\mathrm{Z}$ \\
\hline CA & -0.0027 & -0.39 & 0.701 \\
\hline TA & 0.801 & 6.27 & $0.000 * * *$ \\
\hline AGGA & 0.0324 & 2.87 & $0.005 * * *$ \\
\hline DY & -0.9183 & -3.13 & $0.002 * * *$ \\
\hline cons & 2.869 & 8.38 & $0.000 * * *$ \\
\hline $\begin{array}{c}R \text {-sq. overall } \\
(F-\text { value })\end{array}$ & $\begin{array}{c}38.14 \% \\
215.62 * * *\end{array}$ & & \\
\hline
\end{tabular}

However, the comparisons reveal that affection of the cash flows list and their influence on the shares were lower than those of the accruals.

\section{Conclusions}

In view of the research findings, the researcher reached to various conclusions. First, the cash flows and the accruals, each, affect the share prices of the Jordanian companies significantly. However, the accruals have a higher effect $\left(R^{2} \approx .384\right)$ on the share prices of the Jordanian companies than cash flows $\left(R^{2} \approx .133\right)$. Hence, the stakeholders in Jordan assign a higher value to firm stocks. Therefore, the inclusion of accruals with the cash flows as predictors of share prices of the Jordanian companies in one model increases the prediction power of both individual predictors. The accruals add to the cash flows a remarkable power for prediction of the share prices of the Jordanian companies. This conclusion suggests that the accruals have a much higher information content and value relevance for the listed Jordanian companies than the cash flows. Second, the researcher concludes that the accruals have higher information content and are more value relevant for the industrial Jordanian companies than for the financial or the service companies. Contrarily, the cash flows have higher information content and are more value relevant for the service Jordanian companies than for the industrial or the financial companies. Third, it is concluded that the accounting information prepared under the cash accounting convention is less useful than that prepared under the accrual accounting convention for future share price prediction. Nevertheless, the cash flow information plays an important supplementary role to that of accruals for forecasting the future share prices of companies. Fourth, audit quality has a significant moderating effect on the association of the share prices of the Jordanian companies with the accruals and the cash flows. Auditor's firm size, as one of the two proxies for audit quality employed in this study, has significant moderating effect on the association of the share prices of the Jordanian companies with the TAs and the CAs, but not with the AGGAs. Further, auditor's firm size has significant moderating effects on the association of the share prices of the Jordanian companies with each of the OCFs and ICFs, but not with the FCFs.

Furthermore, auditor's tenure, which is the second proxy for audit quality employed in this study, has significant moderating effects on the association of the share prices of the Jordanian companies with the TAs and the CAs, but not with the AGGAs. Moreover, auditor's tenure has significant moderating effects on the association of the share prices of the Jordanian companies with each of the OCFs and ICFs, but not with the FCFs. Based on the outcomes of the present study, the researcher concludes that (i) the global financial crisis had substantial negative impacts on the share prices of the companies listed on Amman Stock Exchange Market, as well as on association of these prices with the accruals and the cash flows; and (ii) financial information compiled based on the cash flow accounting basis is more sensitive to financial crises than financial information compiled based on the accrual accounting basis owing to that the former was more negatively impacted by the latest global financial crisis than the latter.

Agreement of results of this study with those of earlier studies (e.g., Habibi (2009), Mahran (2011), Jahromi et al. 
(2013), Abubakar et al. (2014), Yaseen et al. (2015), and Onuoha \& Nwaiwu (2016)) as to the deterioration in share prices of companies by effect of the global financial crisis leads to the conclusion that the world markets, developed and developing, are highly and tightly interconnected and interrelated. This also suggests that in such a small stock market as the Jordanian market the drop in the share prices of listed companies is due, at least in part, to globalization and intertwining of this market within the global financial markets. In other respects, since the Jordanian stock market was still suffering from the latest global financial crisis until 2014, and maybe until now, though this crisis actually ended by the end of June 2009, then the researcher concludes that this massive crisis still has some long way ahead to go. Viewed from other perspective, this conclusion, and the related findings, support the argument of Nour and Sharabati (2014) who pointed out that the Jordanian market undergoes delayed recovery due to that nearly all the world markets started recovery from the latest global financial crisis within one year or two years while the Jordanian stock market was, and perhaps is, still suffering from it until now., the researcher reaches to the conclusion that a single financial indicator is not adequate for explaining the movement of the share prices of companies or for anticipating those prices. A second conclusion is that the principal financial indicators have a significantly higher combined effect on the share prices of companies than any individual indicator.

\section{References}

Abubakar, A. Y., Jagongo, A., Almadi, O. J., \& Muktar, B. S. (2014). Effects of 2008 global liquidity crisis on the performance of banks' shares traded in Nigeria Stock Exchange Market. African Journal of Business Management, 8(23), 1094-1100.

Al-Khaddash, H., \& Al-Abbadi, M. (2015). The relationships between each of the accounting revenue and cash flows to shareholders with equity market value of shares. Studies: Management Sciences, 32(1), 141-153 (In Arabic).

Balsam, S., Krishnan, J., \& Yang, J. (2003). Auditor industry specialization and earnings quality. Auditing: A Journal of Practice and Theory, 22(2), 71-97. https://doi.org/10.2308/aud.2003.22.2.71

Caramanis, C., \& Lennox, C. (2008). Audit effort and earnings management. Journal of Accounting and Economics, 45(1), 16-138. https://doi.org/10.1016/j.jacceco.2007.05.002

Charitou, A., Clubb, C., \& Andreou, A. (2001). The effect of earnings permanence, growth and firm size on the usefulness of cash flows and earnings in explaining security returns: empirical evidence for the UK. Journal of Business Finance and Accounting, 28(5-6), 563-594. https://doi.org/10.1111/1468-5957.00385

Cohen, J. (1988). Statistical power analysis for the behavioral sciences. 2nd.

Doyle, J. T., Ge, W., \& McVay, S. E. (2007). Accruals quality and internal control over financial reporting. The Accounting Review, 82(5), 1141-1170. https://doi.org/10.2308/accr.2007.82.5.1141

Drake, M. S., Myers, J. N., \& Myers, L. A. (2009). Disclosure quality and the mispricing of accruals and cash flow. Journal of Accounting, Auditing, and Finance, 24(3), 357-384. https://doi.org/10.1177/0148558X0902400303

Gujarati, D. N., \& Porter, D. (2009). Basic econometrics (5 ${ }^{\text {th }}$ ed.). New York: Mc Graw-Hill International.

Gunny, K., \& Zhang, T. (2009). PCAOB inspection reports and audit quality. Journal of Accounting and Public Policy, 32(2), 136-160. https://doi.org/10.1016/j.jaccpubpol.2012.11.002

Habibi, N. (2009). The impact of the global economic crisis on Arab countries: A Year-end assessment (Crown Center for Middle East Studies Papers, Middle East Brief Paper No. 40). Retrieved from: www.brandeis.edu/crown/publications/meb/MEB40.pdf

Hair, J. F. (2010). Black, WC, Babin, BJ, \& Anderson, RE (2010). Multivariate data analysis, 7.

Henderson, D. J., Carroll, R. J., \& Li, Q. (2008). Nonparametric estimation and testing of fixed effects panel data models. Journal of Econometrics, 144(1), 257-275. https://doi.org/10.1016/j.jeconom.2008.01.005

Jahromi, S. S. D., Yazdi, H. K., \& Sarlak, A. (2013). Investigating the effects of global financial crisis on stock price and operating profit: Evidence from Tehran stock exchange. Management Science Letters, 3, 2387-2392. https://doi.org/10.5267/j.msl.2013.08.030

Khadash, H., Badran, M., \& Nassar, M. (2013). The effect of contextual factors on the information content of cash flows in explaining stock prices- The case of Amman Stock Exchange. Jordanian Journal in Business Administration, 1(1), 121-132.

Keown, A. J., Martin, J. D., Petty, J. W., \& Scott, D. F. S. (2005). Financial management: Principles and 
Application (10 $0^{\text {th }}$ ed.). Upper Saddle River, NJ: Pearson Education.

Khurana, I., \& Raman. K. K. (2004). Are Big 4 audits in ASEAN countries of higher quality than non-Big 4 audits? Asia Pacific Journal of Accounting and Economics, 11(2), 139-165. https://doi.org/10.1080/16081625.2004.10510640

Krishnan, G. V. (2003). auditor quality and the pricing of discretionary accruals. Auditing: A Journal of Practice \& Theory, 22(1), 109-126. https://doi.org/10.2308/aud.2003.22.1.109

Mahran, S. M. R. (2011). Study the impact of the global crisis on stock prices and liquidity in the stock market. Paper presented at the 2011 International Conference on E-business, Management and Economics (IPEDR (pp. 51-59). Singapore: IACSIT Press, Singapore.

Moroney, R. (2007). Does industry expertise improve the efficiency of audit judgment? Auditing: A Journal of Practice \& Theory, 26(2), 69-94. https://doi.org/10.2308/aud.2007.26.2.69

Neuman, W. L. (2006). Social research methods: Qualitative and quantitative approaches (6 ${ }^{\text {th }}$ ed.). Boston: Pearson International.

Okolie, A. O. (2014). Audit quality and earnings response coefficients of quoted companies in Nigeria. Journal of Applied Finance \& Banking, 4(2), 139-161

Okolie, A. O., Izedonmi, F. O. I., \& Enofe, A. O. (2013). Audit quality and accrual-based earnings management of quoted companies in Nigeria. IOSR Journal of Economics and Finance (IOSR-JEF), 2(2), 7-16. https://doi.org/10.9790/5933-0220716

Onuoha, T. E., \& Nwaiwu, J. N. (2016). Impact of global financial crisis on Nigerian stock market. African Research Review, 10(1), 166-177. https://doi.org/10.4314/afrrev.v10i1.13

Oroud, S. Y, Islam, M. A., \& Tunku, S. T. A. (2017). The Effect of Cash Flows on the Share Price on Amman Stock Exchange, American Based Research Journal, 07, 22-28.

Oroud, S. Y., Islam, M. A., \& Tunku S. T. A. (2016). The Effect of Cash Flows and Accruals on The Market Values of Equity: Audit Quality as A Moderator, International Journal of Current Research, 8(03), 28900-28908.

Pallant, J. (2013). SPSS survival manual. London: McGraw-Hill Education.

Penman, S. H., \& Yehuda, N. (2009). The pricing of earnings and cash flows and the affirmation of accrual accounting. Review of Accounting Studies, 14(4), 453- 479. https://doi.org/10.1007/s11142-009-9109-4

Pourheydari, O., \& Ahmadi, S. A. (2008). Accruals and cash flows in equity valuation: Iranian case. Middle Eastern Finance and Economics, 2, 5-15.

Reynolds, J. K., \& Francis, J. (2000). Does size matter? The influence of large clients on office-level auditor reporting decisions. Journal of Accounting and Economics, 30(3), 375-400.

https://doi.org/10.1016/S0165-4101(01)00010-6

Watson, D., \& Head, T. (2007). Corporate finance: Principles and practice $\left(4^{\text {th }}\right.$ ed.). London: Pearson Education.

Yaseen, H., Omet, G., \& Abdel-Halim, M. (2015). The 2008 Global financial crisis: The case of a market with consistent losses ever since. Eurasian Journal of Business and Management, 3(1), 8-19.

https://doi.org/10.15604/ejbm.2015.03.01.002

Zikmund, W. G. (2000) Business Research Methods. 6th Edition, The Dryden Press, Fort Worth.

\section{Copyrights}

Copyright for this article is retained by the author(s), with first publication rights granted to the journal.

This is an open-access article distributed under the terms and conditions of the Creative Commons Attribution license (http://creativecommons.org/licenses/by/4.0/). 